\title{
A STUDY OF COMMON MORBIDITIES AMONG ADOLESCENT GIRLS IN THE URBAN SLUMS OF SILCHAR, ASSAM
}

\author{
Ajoy Bhusan Nath ${ }^{1}$
}

${ }_{1}^{1}$ Assistant Professor, Department of Community Medicine, Silchar Medical College and Hospital, Silchar, Assam.

$\overline{\text { BACKGROUND }}$

Adolescent problems constitute a bulk of morbidities, which are unrecognised and uncared among iceberg of disease burden. Adolescent girls are the mothers of tomorrow, hence the health of the girls of today will affect the health and survival of the future generation.

The objective of this study is to study the common morbidities among the adolescent girls and to assess the various sociodemographic correlates affecting the morbidities in the urban slums of Silchar, Assam.

\section{MATERIALS AND METHODS}

A cross-sectional study was conducted in the urban slums of Silchar, Assam, from June 2016 to May 2017 among 500 adolescent girls aged 10 to 19 years. The data were collected in a predesigned and pretested schedule by interview method and house to house visit in the selected slums, so as to cover the desired sample. During home visits, socio-demographic profile of the family was taken along with the interview and examination of adolescent girls.

\section{RESULTS}

In the present study, it was observed that $69.20 \%$ adolescent girls were suffering with one or more morbid conditions. The leading cause of morbidity found were pediculosis (42.77\%), menstrual disorder (32.66\%), skin problem (16.76\%), dental problem $(13.58 \%)$ and worm infection (11.56\%). Pallor (10.69\%), defective vision (8.67\%), abdominal disorder (6.65\%) and ear problem (4.62\%) were also observed among the adolescent girls. Significant relation of morbidity in the girls with religion, caste, socioeconomic status, education, family type, diet and personal hygiene was seen.

\section{CONCLUSION}

It was found from this study that the morbidities among adolescent girls in the slum areas were much higher. A significant association between the various socio-demographic correlates affecting the morbidities suggest a need to develop strategies for intensive adult education and to improve the living standard of population. Health education may be useful for improving the health status of adolescent girls with the help of health personnel and Non-Government agencies. Besides, there is an urgent need for accessible health services for adolescent girls in the slum areas.

\section{KEYWORDS}

Adolescent, Morbidity, Socio-Demographic Factor, Urban Slums.

HOW TO CITE THIS ARTICLE: Nath AB. A study of common morbidities among adolescent girls in the urban slums of Silchar, Assam. J. Evolution Med. Dent. Sci. 2017;6(90):6304-6308, DOI: 10.14260/jemds/2017/1371

\section{BACKGROUND}

Adolescence has been defined by the World Health Organisation as the period of life spanning the ages between 10 to 19 years. Adolescence is a transition phase through which a child becomes an adult. It is characterised by rapid growth and development, physically, psychologically and socially.(1) Today, $84 \%$ of the world's adolescents live in the developing world. In our country, there are an estimated 200 million adolescents, comprising one-fifth of the total population.(2) Since decades, a female from birth till death has been a neglected segment of population. Health of the girls of today will affect the health and survival of the future generation. Adolescent girls are the mothers of tomorrow and no edifice

'Financial or Other Competing Interest': None.

Submission 12-09-2017, Peer Review 05-11-2017,

Acceptance 11-11-2017, Published 20-11-2017.

Corresponding Author:

Dr. Ajoy Bhusan Nath,

Assistant Professor,

Department of Community Medicine,

Silchar Medical College and Hospital,

Silchar-788014, Assam.

E-mail: abnath01@gmail.com

DOI: $10.14260 /$ jemds $/ 2017 / 1371$

\section{(c) $(1) \ominus$}

can be built on a foundation that is weak, and if we could not give a safe and secure today to the mother of tomorrow it will be futile to expect the future generation to be mentally and physically healthy.(3)

Adolescent problems constitute a bulk of morbidities, which are unrecognised and uncared among iceberg of disease burden. A large variety of morbidities among adolescents are related with nutritional deficiency disorders (stunting, wasting), menstrual disorders, RTI/ STI/ AIDS etc. Moreover, the complex psychological morbidities and highrisk behaviour of adolescents have been recognised as a threat to survival, growth and development.(4) Majority of adolescents still do not have access to information and education on sexuality, reproduction, sexual and reproductive health and rights, nor do they have access to preventive and curative services. (5)

The adolescent girls of urban slums in Silchar, Assam living in a condition of unhealthy, disease conductive, lack of safe drinking water, housing and environmental sanitation. Slums were initially thought to be temporary phenomena, but this decade has seen that slums are here to stay as long as the "pull" force of urban prosperity and the "push" force of rural poverty stays.(6) So far very few studies had been conducted in North East states, especially in Assam, particularly in the 
urban slum areas. The present study will give sufficient information regarding the extent of adolescent health problems among slum girls.

Thus, keeping in mind all those facts, the study had been undertaken in the urban slum of Silchar, Assam with the following objectives-

1. To study the common morbidities among the adolescent girls, and

2. To assess the various socio-demographic correlates affecting the morbidities.

\section{MATERIALS AND METHODS}

A community-based cross-sectional study was conducted among the adolescent girls aged 10 to 19 years in the urban slums of Silchar, Assam. Approval from the Ethical Committee Silchar Medical College and Hospital, Silchar was taken prior to conduct the study; 500 adolescent girls from 10 slums were taken up for the study. We selected $50 \%$ of the total slums, i.e. 10 slums out of 19 urban slums of Silchar town as identified by Silchar Municipal Board by random sampling method. Then for uniform distribution of total number of respondents in each slum it was decided to take 50 respondents per slum, thus the total number of respondents came to 500 .

The data were collected from June 2016 to May 2017 in a predesigned and pretested questionnaire by interview method including physical examination and house to house visit in selected slum.

During home visits, demographic profile of the family was taken along with the interview and examination of the adolescent girls. Adolescent girls of the family were interviewed using oral questionnaire method. If any of the adolescent girls in the family was absent during the time of study, the girls in the next family was interviewed. For proper response, the head of the families were explained in detail the purpose of the study. Oral consent from the head of the family and the adolescent girl was taken. The physical examination of the girl was done in presence of mother and in her absence any other senior female member of the family. Each girl was examined physically from head to toe and any signs and symptoms of illnesses were recorded. Besides a detail information was collected on a predesigned and pretested questionnaire about socio-demographic characteristics and the other contributory factor responsible for health.

The study instruments used were stethoscope, sphygmomanometer, Torch light, Snellen's chart etc. to detect the common morbidities. The socio-economic status was determined as per the modified BG Prasad method of socioeconomic classification updated with CPI Index, April 2016.

The data collected on various aspects of study were complied, tabulated and statistical analysis were done manually subjecting the data to the statistical tests. Data were analysed using percentages and Pearson's Chi-square test $\left(\chi^{2}\right)$ for normal distribution. $P$ value of less than 0.05 were considered significant.

\begin{tabular}{|c|c|c|}
\hline $\begin{array}{c}\text { Age Group } \\
\text { (in years) }\end{array}$ & $\begin{array}{c}\text { No. of Adolescent } \\
\text { Girls }\end{array}$ & Percentage \\
\hline $10-13$ & 192 & 38.4 \\
\hline $14-15$ & 124 & 24.8 \\
\hline $16-19$ & 184 & 36.8 \\
\hline Total & $\mathbf{5 0 0}$ & $\mathbf{1 0 0 . 0}$ \\
\hline \multicolumn{3}{|c|}{ Table 1. Distribution of Adolescent Girl according to Age } \\
Group
\end{tabular}

\begin{tabular}{|c|c|c|}
\hline Morbidity & No. of Adolescent Girls & Percentage \\
\hline Present & 346 & 69.2 \\
\hline Absent & 154 & 30.8 \\
\hline Total & $\mathbf{5 0 0}$ & $\mathbf{1 0 0 . 0}$ \\
\hline \multicolumn{2}{|c|}{ Table 2. Distribution of Adolescent Girls according to } \\
Morbidity \\
\hline
\end{tabular}

\begin{tabular}{|c|c|c|}
\hline Morbidities & $\begin{array}{c}\text { No. of Adolescent } \\
\text { Girls (n= 346) }\end{array}$ & Percentage \\
\hline Skin problems & 58 & 16.76 \\
\hline Pediculosis & 148 & 42.77 \\
\hline Pallor & 37 & 10.69 \\
\hline Dental problem & 47 & 13.58 \\
\hline Ear disease & 16 & 4.62 \\
\hline Defective vision & 30 & 8.67 \\
\hline Worm infestation & 40 & 11.56 \\
\hline Menstrual disorder & 113 & 32.66 \\
\hline Respiratory problem & 18 & 5.20 \\
\hline Abdominal disorder & 23 & 6.65 \\
\hline Cardiovascular problem & 3 & 0.86 \\
\hline Psychological problem & 8 & 2.31 \\
\hline \multicolumn{2}{|c|}{ Table 3. Distribution of Common Morbidities among } \\
\hline \multicolumn{2}{|c|}{ Adolescent Girls } \\
\hline
\end{tabular}

NB. Respondents have given multiple responses.

\begin{tabular}{|c|c|c|c|}
\hline Religion & $\begin{array}{c}\text { No. of Adolescent } \\
\text { Girls }\end{array}$ & $\begin{array}{c}\text { Morbidity } \\
\text { Present }\end{array}$ & Percentage \\
\hline Hindu & 261 & 153 & 58.62 \\
\hline Muslim & 239 & 193 & 80.75 \\
\hline Total & $\mathbf{5 0 0}$ & $\mathbf{3 4 6}$ & $\mathbf{6 9 . 2 0}$ \\
\hline \multicolumn{3}{|c|}{ Table 4. Distribution of Adolescent Girls according to } \\
Religion and Morbidity \\
\hline
\end{tabular}

$\chi^{2}=28.67, \mathrm{df}=1, \mathrm{P}<0.001$

\begin{tabular}{|c|c|c|c|}
\hline Caste & $\begin{array}{c}\text { No. of } \\
\text { Adolescent Girls }\end{array}$ & $\begin{array}{c}\text { Morbidity } \\
\text { Present }\end{array}$ & Percentage \\
\hline General & 251 & 146 & 58.16 \\
\hline O.B.C & 78 & 59 & 75.64 \\
\hline S.C & 171 & 141 & 82.46 \\
\hline Total & $\mathbf{5 0 0}$ & $\mathbf{3 4 6}$ & $\mathbf{6 9 . 2 0}$ \\
\hline \multicolumn{4}{|c|}{ Table 5. Distribution of Adolescent Girls according to Caste } \\
and Morbidity \\
\hline
\end{tabular}

$\chi^{2}=29.96, \mathrm{df}=2, \mathrm{P}<0.001$

\begin{tabular}{|c|c|c|c|}
\hline $\begin{array}{c}\text { Socio- } \\
\text { Economic } \\
\text { Status } \\
\end{array}$ & $\begin{array}{c}\text { No. of } \\
\text { Adolescent Girls }\end{array}$ & $\begin{array}{l}\text { Morbidity } \\
\text { Present }\end{array}$ & Percentage \\
\hline Class I & 8 & 1 & 12.5 \\
\hline Class II & 51 & 14 & 27.45 \\
\hline Class III & 76 & 32 & 42.11 \\
\hline Class IV & 261 & 208 & 79.69 \\
\hline Class V & 104 & 91 & 87.5 \\
\hline Total & 500 & 346 & 69.20 \\
\hline \multicolumn{4}{|c|}{$\begin{array}{c}\text { Table 6. Distribution of Adolescent Girls according to Socio } \\
\text { Economic Status and Morbidity }\end{array}$} \\
\hline
\end{tabular}

$\chi^{2}=109.78, \mathrm{df}=4, \mathrm{P}<0.001$ 


\begin{tabular}{|c|c|c|c|}
\hline $\begin{array}{c}\text { Educational } \\
\text { Status }\end{array}$ & $\begin{array}{c}\text { No. of } \\
\text { Adolescent } \\
\text { Girls }\end{array}$ & $\begin{array}{c}\text { Morbidity } \\
\text { Present }\end{array}$ & Percentage \\
\hline Illiterate & 151 & 123 & 81.46 \\
\hline Primary School & 122 & 92 & 75.41 \\
\hline Middle School & 101 & 73 & 72.28 \\
\hline High School & 76 & 46 & 60.53 \\
\hline $\begin{array}{c}\text { HSLC passed } \\
\text { and above }\end{array}$ & 50 & 12 & 24.0 \\
\hline Total & 500 & 346 & 69.20 \\
\hline Table 7. Distribution of Adolescent Girls according to \\
Education and Morbidity \\
\hline
\end{tabular}

$\chi^{2}=63.93, \mathrm{df}=4, \mathrm{P}<0.001$

\begin{tabular}{|c|c|c|c|}
\hline $\begin{array}{c}\text { Family } \\
\text { Type }\end{array}$ & $\begin{array}{c}\text { No. of Adolescent } \\
\text { Girls }\end{array}$ & $\begin{array}{c}\text { Morbidity } \\
\text { Present }\end{array}$ & Percentage \\
\hline Nuclear & 342 & 219 & 64.04 \\
\hline Joint & 158 & 127 & 80.38 \\
\hline Total & $\mathbf{5 0 0}$ & $\mathbf{3 4 6}$ & $\mathbf{6 9 . 2 0}$ \\
\hline
\end{tabular}

Table 8. Distribution of Adolescent Girls according to Type of Family and Morbidity

$\chi^{2}=13.54, \mathrm{df}=1, \mathrm{P}<0.001$

\begin{tabular}{|c|c|c|c|}
\hline Diet & $\begin{array}{c}\text { No. of } \\
\text { Adoscent Girls }\end{array}$ & $\begin{array}{c}\text { Morbidity } \\
\text { Present }\end{array}$ & Percentage \\
\hline Vegetarian & 153 & 126 & 82.35 \\
\hline $\begin{array}{c}\text { Non- } \\
\text { Vegetarian }\end{array}$ & 347 & 220 & 63.40 \\
\hline Total & $\mathbf{5 0 0}$ & $\mathbf{3 4 6}$ & $\mathbf{6 9 . 2 0}$ \\
\hline Table 9. Distribution of Adolescent Girls according to Diet \\
and Morbidity \\
\hline
\end{tabular}

$\chi^{2}=17.89, \mathrm{df}=1, \mathrm{P}<0.001$

\begin{tabular}{|c|c|c|c|}
\hline $\begin{array}{c}\text { Personal } \\
\text { Hygiene }\end{array}$ & $\begin{array}{c}\text { No. of } \\
\text { Adolescent Girls }\end{array}$ & $\begin{array}{c}\text { Morbidity } \\
\text { Present }\end{array}$ & Percentage \\
\hline Satisfactory & 171 & 70 & 40.94 \\
\hline Poor & 329 & 276 & 83.89 \\
\hline Total & $\mathbf{5 0 0}$ & $\mathbf{3 4 6}$ & $\mathbf{6 9 . 2 0}$ \\
\hline
\end{tabular}

Table 10. Distribution of Adolescent Girls according to General Personal Hygiene and Morbidity

$\chi^{2}=97.4, \mathrm{df}=1, \mathrm{P}<0.001$

\section{RESULTS}

In the present study, 500 adolescent girls were interviewed and examined for sickness in the urban slums of Silchar, Assam. It was observed that 346 (69.2\%) adolescent girls were suffering with one or more morbid conditions (Table 2). The highest number 192 (38.4\%) of adolescent girls were found in the age group of 10 to 13 years (Table 1).

It was found that the leading cause of morbidity were pediculosis (42.77\%), menstrual disorder (32.66\%), skin problem (16.77\%), dental problem (13.58\%), worm infestation (11.56\%), pallor (10.69\%) and defective vision (8.67\%) (Table 3).

So far as the region is concerned, the morbidities among the Muslim adolescent girls was seen the highest (80.75\%) than Hindu (58.62\%) (Table 4). Regarding caste, the morbidity was seen maximum in scheduled caste adolescent girls (82.46\%) (Table 5). It was also found that the prevalence of morbidity was highest in girls of lower socio-economic status (87.5\%) (Table 6).

In the present study, it was observed that the prevalence of morbidity was highest in illiterate girls (81.46\%) (Table 7).
Again, among the girls of joint families, the morbidities were more $(80.38 \%)$ than nuclear families (64.04\%) (Table 8).

It was also found that the vegetarian girls were suffering with more morbid conditions (82.35\%) than the nonvegetarians (63.40\%) (Table 9). Moreover, among the adolescent girls with poor personal hygiene, the prevalence of morbidity was seen higher (83.89\%) (Table 10).

\section{DISCUSSION}

In the present study, it was observed that the morbidity among the adolescent girls in the urban slums of Silchar, Assam was $69.2 \%$. Kajal Jain et al(7) in their study at western Uttar Pradesh found $63.7 \%$ of adolescent girls were suffering with one or more morbid conditions. Beena Sachan et al(3) also noticed in their study among school going girls in Lucknow district that around $64.8 \%$ girls were sick at the time of study.

In another study by Srinivasan $\mathrm{K}$ et al(8) in Tirupati town of Andhra Pradesh revealed $94.5 \%$ of girls having one or more morbid conditions. A study by Basu et al(9) it was seen that only $13.6 \%$ girls were without any health problem, but $86.4 \%$ had one or more health problems. The present study thus corroborates with the above studies of different workers.

It was observed in the present study that the majority girls were suffering from pediculosis (42.77\%), menstrual disorder (32.66\%), dental problem (13.58\%), worm infestation (11.56\%) and pallor (10.69\%). Besides, defective vision $(8.67 \%)$, abdominal disorder (6.65\%), psychological problem $(2.31 \%)$ and cardiovascular problem $(0.86 \%)$ were also noticed.

KM Susmitha et al(9) in their study at Nellore city, AP, India found $83.2 \%$ girls were suffering from pediculosis, dysmenorrhea (43.6\%), dental problem (28.04\%), worm infestation (13.28\%), pallor $(41.14 \%)$, defective vision (12.36\%), ENT disorder (7.01\%) and cardiovascular disorders (1.11\%).

Another study conducted in urban slum of Lucknow by Singh et al(10) on 400 adolescent girls aged 10 - 19 years, the various morbid conditions found were inadequate oral hygiene (55.4\%), pediculosis (39.2\%), cold and cough (25.8\%), inflamed tonsil (7.8\%) and ear discharge (7\%).

Kajal Jain et al(7) in their study at western Uttar Pradesh among urban adolescent girls also found that the various morbidities were nutritional anaemia (62.2\%), psychological (20.3\%), infective and parasitic (10.9\%), digestive $(10.9 \%)$, eye $(8.5 \%)$, respiratory $(5.1 \%)$, skin $(3.5 \%)$ and ear problem $(2.7 \%)$.

Anita et al(11) in Rohtak reported anaemia (55.5\%), dysmenorrhea (43\%), dental caries $(37.2 \%)$, pediculosis (31\%), URTI (17.5\%), refractive error (13\%) and acne $(11 \%)$ among adolescent girls.

A study conducted by Beena Sachan et al(3) among school going adolescent girls in Lucknow district revealed that the morbidities were hair problem (16.4\%), teeth and gum $(14.2 \%)$ and eye disorder (11.7\%).

Srinivasan $\mathrm{K}$ et $\mathrm{al}^{(8)}$ in their study also described the common morbidities found were skin disorder $(25.7 \%)$ and dental caries $(21.5 \%)$.

Geetha et al(12) in their study at Kaniyambadi Block of North Arcot district of Tamil Nadu amongst girls of rural community the leading morbidities found were general fatigue, palpitation, backache and abdominal pain. 
Similar study conducted by Agarwal et al(13) in Mumbai among 1144 girls aged 5 - 15 years' age group observed that the common health problems were hygiene related (62.2\%), dental caries and helminthiasis were common in younger girls, pediculosis in older girls, $6.6 \%$ asthma and $0.5 \%$ cardiac diseases. These studies, the different workers mentioned above corroborate with the present study.

Again, another study conducted by Mishra A et al(14) among school going adolescent girls in Delhi found that the most common psychological morbidity was anxiety and depression which accounted for almost $10 \%$ of all the problems which were faced by adolescents.

Similar study conducted at Thiruvananthapuram, India by Nair MKC et al,(15) the psychological morbidity like depression was found in $2.6 \%$. The present study revealed psychological morbidities in $2.31 \%$, which corresponded with the study of Nair MKC et al.

In the present study, it was also observed that among the Muslim girls the morbidities were higher (80.75\%) than Hindu girls (58.62\%). These differences were found statistically significant $(\mathrm{P}<0.001)$. Beena Sachan et al(3) also found the higher prevalence of morbidities among Muslim girls in their study.

It was also observed in the present study that the adolescent girls that belonged to General Caste has less morbidity (58.16\%) than other backward classes (75.64\%), and scheduled caste (82.46\%). These association between caste and morbidity were found statistically significant $(\mathrm{p}<0.001)$.

Beena Sachan et al(3) in their study also found that the General caste had less morbidity than other backward classes and Scheduled caste.

Kajal Jain et al(7) mentioned in their study that the morbidity was higher in OBC $(81.8 \%)$ followed by SC $(69.2 \%)$ and least in General caste (55.8\%). The present study was thus found to be similar with the above studies.

In the present study, it was found that the socio-economic status had a great role over morbidities of the adolescent girls. Majority of the girls with morbidity belonged to low socio-economic status (87.5\%). This association between morbidity and socio-economic status was found significant $(\mathrm{P}<0.001)$. Similar observations were also noticed by other workers $(3,7)$ in their studies.

The present study showed that the morbidity amongst the illiterate girls were higher $(81.46 \%)$ than the girls having primary education (75.41\%) followed by High school standard (60.53\%) and HSLC passed and above (24\%). This relationship between education and morbidity was found statistically significant $(\mathrm{P}<0.001)$.

The study also revealed that the morbidities were higher $(80.35 \%)$ in girls of joint families than that of nuclear families $(64.04 \%)$ and this was found to be statistically significant $(p<0.001)$. This may be because of non-availability of enough high quality and nutritious food for every member of the joint families and also the dilution of house-hold resources and mother's attention towards children. Similar observations were also described by other workers. $(3,7)$

It was observed in the present study that the girls suffering with more morbid conditions were vegetarian $(82.35 \%)$ than non-vegetarians $(63.40 \%)$. This relationship between diet and morbidity was found statistically significant
$(\mathrm{P}<0.001)$. Kajal Jain et al(7) also found similar findings in the studies.

It was also found in the present study that the morbidity was significantly higher in girls with poor personal hygiene $(83.89 \%)(\mathrm{P}<0.001)$. Beena Sachan et al(3) also mentioned in their study that the morbidities were higher amongst girls of poor personal hygiene. Agarwal et al(13) also observed in their study at Mumbai amongst 1144 girls that the common health problems were hygiene related (62.2\%). Hence, care should be taken to improve the status of personal hygiene of adolescent girls, through coordinated primordial and primary preventive measures like health education.

\section{CONCLUSION}

Adolescence should be considered as a special group in developmental, educational and health programme. Education of females is a driving force for better health. A significant association of morbidity with religion, caste, socioeconomic status, education, family type, diet and personal hygiene in the present study suggests a need to develop strategies for intensive adult education and to improve the standard of living of the population.

Health Education may be useful for improving the health status of adolescent girls with the help of health personnel and Non-Governmental Organisation by regular screening programme instituted in target areas like schools and colleges where a large number of adolescents get together.

In addition to health awareness, preventive, promotive and curative accessible health services to be initiated in the slum areas for the improvement of physical as well as psychosocial health status of the slum population in general and adolescent girls in particular. Besides, simple measures like improvement of personal hygiene and instituting safe hygiene practices by adolescent girls can go a long way in reducing morbidities. Adolescent girls are the mothers of tomorrow, so their morbid conditions should be recognised early and solutions should be provided accordingly, else we lose millions of perfect mothers in future.

\section{Limitation of Study}

The present study of morbidities among adolescent girls was conducted in the urban slums of Silchar town. Hence, further such studies in different areas are required to conform the present findings and specific multipronged intervention models are to be designed to address the menace of morbidities in adolescent girls.

\section{REFERENCES}

[1] WHO Adolescent Nutrition: a review of the situation in selected south east Asian countries, 2006.

[2] Women in India: a statistical profile. Department of women and child development, ministry of HRD, GOI, 1997.

[3] Sachan B, Idris MZ, Jain S, et al. Social determinants and its influence on the prevalence of morbidity among adolescent girls. N Am J Med Sci 2012;4(10):474-8.

[4] Biswas R. In search of adolescent health care. Indian J Public Health 2004;48(4):155-6.

[5] National Family Health Survey NFHS-3 India, 2005-06, International Institute for Population Sciences, Mumbai, India. 
[6] Potdar, Ramesh D. Training of paediatric primary care in Urban ghettos and slum. International Child Health 1994;5(4):11-3.

[7] Jain K, Agarwal D, Gupta SK. High morbidity among urban adolescent females: a cause for concern. International Journal of Contemporary Medical Research 2016;3(4):961-4.

[8] Srinivasan K, Prabhu GR. A study of the morbidity status of children in social welfare hostels in Tirupati town. Indian Journal of Community Medicine 2006;31(3):170.

[9] Susmitha KM, Jyothi C, Prabhakaran J. Morbidity pattern among adolescent girls: a study in the social welfare hostel for scheduled castes, Nellore city, A.P, India. Nat J Res Com Med 2012;1(1):1-60.

[10] Singh J, Singh JV, Srivastava AK. Health status of adolescent girls in slums of Lucknow. Indian Journal of Community Medicine 2006;31(2):102.
[11] Anita Gaur DR, Subhash S. Morbidity pattern of adolescent girls in higher secondary school girls, Rohtak. P-92, Sauvenir, XXX National Conference, Indian Association of Preventive and Social Medicine Belgaum, 2003.

[12] Joseph GA, Bhattacharji S, Joseph A, et al. General and reproductive health of adolescent girls in rural south India. Indian Pediatr 1997;34(3):242-5.

[13] Agarwal M, Ghildiyal R, Khopkar S. Health status of social girls from affluent population of Mumbai, Indian. Paediatrics 1999;36:75-8.

[14] Mishra A, Sharma AK. A clinico-social study of psychiatric morbidity in 12 to 18 years school going girls in urban Delhi. Indian J Community Medicine 2001;26(2):71.

[15] Nair MK, Paul MK, John R. Prevalence of depression among adolescents. Indian J Pediatr 2004;71(6):523-4. 